\title{
SYN-RIFT FLUVIO-LACUSTRINE DEPOSITIONAL SYSTEM OF THE CRETACEOUS BIMA FORMATION IN THE GONGOLA SUB - BASIN, NORTHERN BENUE TROUGH, NE, NIGERIA
}

\author{
Shettima Bukar ${ }^{1} \mathbb{}$, , Mohammed Bukar ${ }^{1}$, Fatima Dupe Adams ${ }^{1}$ \\ ${ }^{1}$ Department of Geology, University of Maiduguri, Nigeria
}

DOI: https://doi.org/10.29121/granthaalayah.v8.i9.2020.1327

Article Type: Research Article

Article Citation: Shettima Bukar, Mohammed Bukar, and Fatima Dupe Adams. (2020). SYN-RIFT FLUVIOLACUSTRINE DEPOSITIONAL SYSTEM OF THE CRETACEOUS BIMA FORMATION IN THE GONGOLA SUB - BASIN, NORTHERN BENUE TROUGH, NE, NIGERIA. International Journal of Research GRANTHAALAYAH, 8(9), 54-62. https://doi.org/10.29121/granthaa layah.v8.i9.2020.1327

Received Date: 28 August 2020

Accepted Date: 25 September 2020

Keywords:

Syn-Rift

Fluvio-Lacustrine

Depositional System

Basin

\section{ABSTRACT}

The facies analysis of the syn-rift sequences Bima I Formation in the Gongola Sub-basin of the Northern Benue Trough displayed assemblages of trough crossbedded sandstones facies, planar crossbedded sandstone facies, massive bedded sandstone facies, ripple laminated sandstone facies, parallel bedded sandstone facies and mudstones facies. These arrays of facies form two suites of facies association that consist of the lacustrinedelta complex depicting coarsening upward cycles and fluvial complexes showcasing fining upwards cycle the former accounts for a scenario where the incremental accommodation is lower than the sediment discharge, whereas the latter is reflective of a case where improved subsidence rate induces high accommodation rate that outruns sediment supply. The stratigraphic architecture of the syn-rift Bima I Formation indicated that the lacustrine-delta are restricted to the lower stratigraphic horizons whereas the fluvial complexes essentially defines the upper stratigraphic zones of this formation.

\section{INTRODUCTION}

The intracratonic Benue Trough located in Nigeria is part of the chain of basins in the West and Central African Rift System, falling in between the Chad and Niger/Delta Basins. It stretches for over $1000 \mathrm{~km}$ in length and varies in width between $50-150 \mathrm{~km}$ (Fig.1), and host more than $6000 \mathrm{~m}$ of Cretaceous - Tertiary sediments associated with volcanics (Fig.2). Geographically, the basin is sub - divided into Northern, Central and Southern portion with Northern Benue Trough constituting of the Gongola, Yola and Muri - Lau Sub - basins (Dike, 2002). The trough evolved as a consequence of the break - up of the African and South American plates during the Late Jurassic - Early Cretaceous times (Genik, 1992). Though, its origin remained controversial owing to contrary theories of rift model (Fairhead et al., 2013) and sinistral wrench faulting model (Benkhelil, 1989). Nonetheless, its evolution and basin architecture is quite defined with horst and graben system, typical of rift basin (Shettima, 2016). The opening of this trough is accompanied with Aptian - Albian marine transgression that terminated in the Central Benue Trough, leaving continental depositional processes to dominate the Northern Benue Trough, thereby depositing the syn and

(C) 2020 The Author(s). This is an open access article distributed under the terms of the Creative Commons Attribution License, which permits unrestricted use, distribution, and reproduction in any medium, provided the original author and source are credited. 
post - rift sequences of the continental Bima Formation (Guiraud, 1990).This depositional regime is synonymous to the Bornu Basin in Nigeria (Avbovbo et al., 1986) and contemporaneously represents the basal sedimentary sequences of the Doba, Deseo, Salamat, Grein, Kafra, Termit, Tenere and Mugland Basins of the West and Central African Rift System (Genik, 1992). Stratigraphic architectures of rift systems are commonly disposed with alluvial fan, lacustrine and fluvial packages (Schlische and Olsen, 1990) but owing to varying sedimentation and tectonics, several depositional packages may evolve (Smooth, 1991). These varying packages have strong implication on the petroleum system of these basins, hence the need to re-evaluate the Bima Formation in this perspective. Therefore, this present research aims to examine in detail the facies association and clay mineralogy of the entire Cretaceous Bima Formation of the Gongola Sub - basin, with an objective of establishing depositional styles and paleoenvironments.

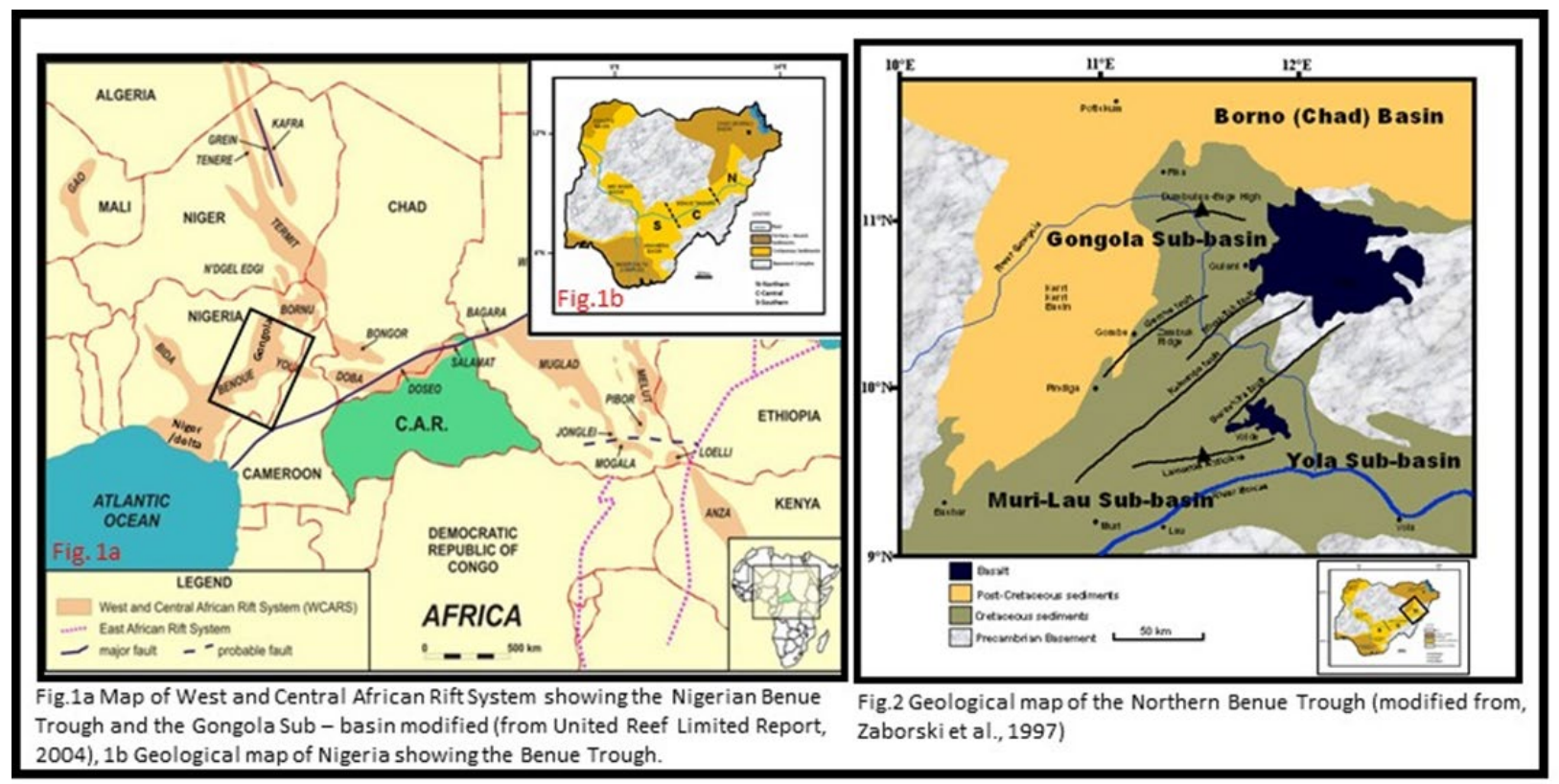

\section{GEOLOGICAL AND STRATIGRAPHIC SETTING}

The Nigerian Benue Trough is a rift basin that falls into the Central West Africa and extends in NNE-SSW direction for about $1000 \mathrm{~km}$ in length and 50-150 km in width (Genik, 1992; Nwajide 2013). The southern fringes is the northern boundary of the Niger Delta, while the northern end is at the Dumbulwa-Bage High, which marks the southern boundary of the Chad Basin (Fig.1) (Zaborski et al., 1997). The Benue Trough is geographically subdivided into Northern, Central and Southern Benue Trough (Fig.1). The Northern Benue Trough is made up of three arms: the N-S striking Gongola Arm, E-W striking Yola Arm and the NE-SW striking Muri-Lau Arm (Dike, 2002) (Fig.2). The Trough is over $6000 \mathrm{~m}$ deep containing Cretaceous to Tertiary sediments of which those predating the midSantonian have been tectonically deformed, to form major faults and fold systems across the basin. The Bima Group of the Aptian-Albian represents the oldest sedimentary units in the Gongola Sub-basin, conformably overlying the Basement Complex Rocks (Fig.3) (Guiraud,1990; Zaborski et al., 1997; Tukur et al., 2015; Shettima et al., 2018). The deposition of syn-rift sequences thereof is largely controlled by the horst and graben systems and is represented by the alluvial fan-lacustrine deposits of the Bima I Formation, the lowermost in the group, which is unconformably superposed by the post-rift braided river sequences of the Bima II and III Formations (Zaborski et al., 1997; Tukur et al., 2015; Shettima et al., 2018). The Yolde Formation conformably succeeded in the Cenomanian, marked by the transitional-marine deposits (Shettima et al., 2011), representing the onset of the mid-Cretaceous global marine transgression in the basin (e.g. Haq et al.,1987). This reached its climax in the Turonian and deposited the shallow marine shale and limestone sequences of the Kanawa Member of the Pindiga Formation (Zarborski et al., 1997; Abdulkarim et al., 2017). Regressive Sandy Members of the Dumbulwa, Deba-Fulani and Gulani Sandstones conformably followed in the mid-Turonian with decelerating transgressive conditions (Fig.3) (Zaborski et al., 1997; Nwajide, 2013). Renewed rising relative sea levels in the late Turonian transcending into the Coniacian and early 
Santonian brought about the deposition of the deep marine blue-black shales of the Fika Member, representing the youngest units of the Pindiga Formation (Zaborski et al., 1997; Shettima, 2016). This marine transgression is accompanied by compressional tectonics in the mid-Santonian (Genik, 1993), which resulted from changing orientation of the displacement vectors between the African plate and European/Tethys plates (Fairhead and Binks, 1991). Thus, leading to thrusting of the pre-Maastrichtian sediments towards the western regions of the Gongola Sub-basin, thereby creating an accommodation for the deposition of the Campano-Maastrichtian regressive deltaic sequences of the Gombe Formation (Dike and Onumara, 1999: Shettima, 2016). The mid-Maastrichtian is characterized by yet another phase of compressional event and it is followed by the unconformable deposits of the Paleogene fluvio-lacustrine Kerri Kerri Formation (Dike, 1993: Adegoke et al., 1978) (Fig.3). volcanics are evident in the Paleogene-Neogene phase of the sub-basin, commonly align along the eastern margin of the Gongola Sub-basin (Wilson and Guiraud, 1992).

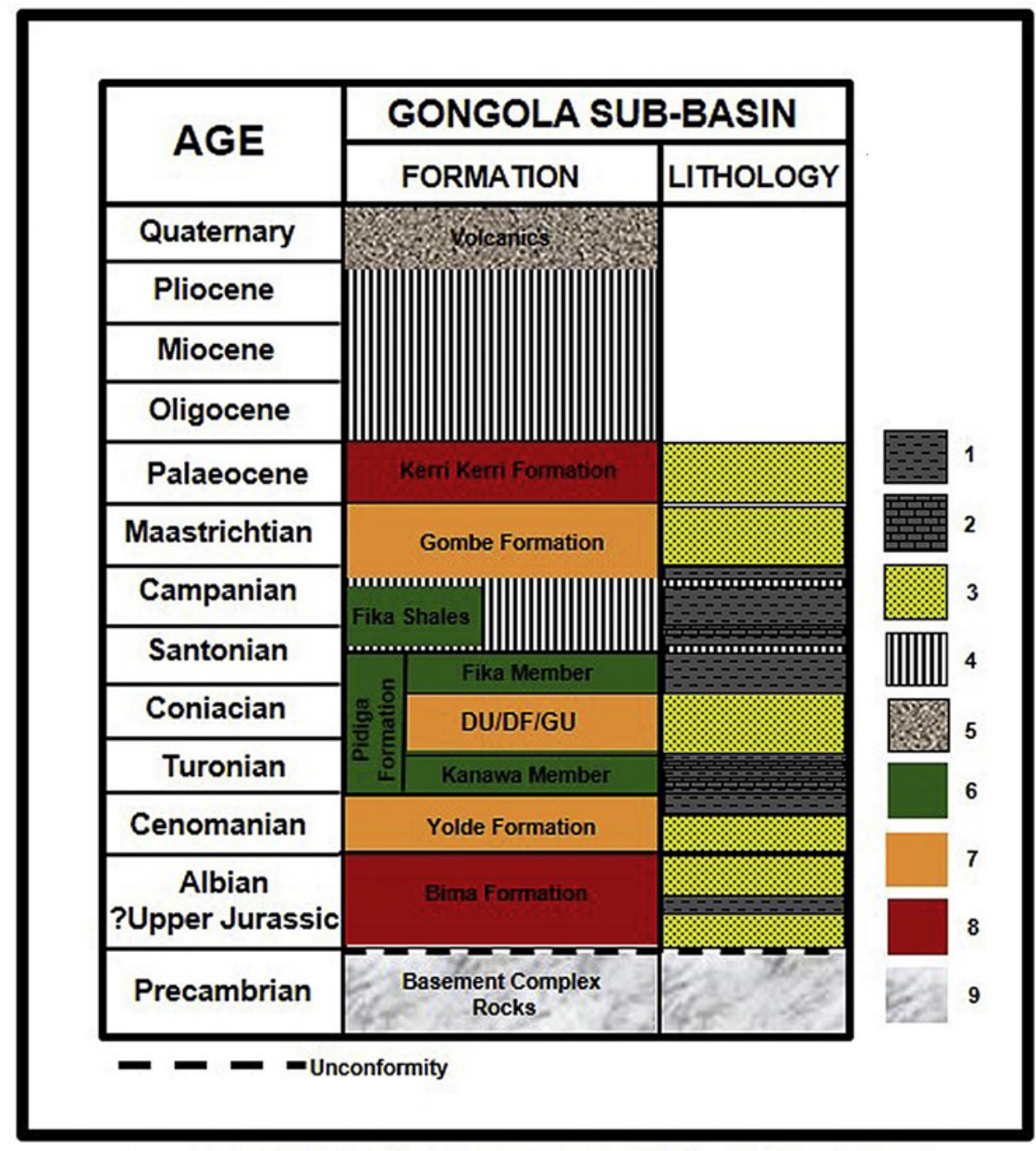

Fig. 2 Showing the stratigraphy of the Gongola Sub-basin (modified from Zaborski et al., 1997). 1-Mudstone, 2-Limestone, 3-Sandstone, 4-Hiatus, 5-Basalt, 6-Marine sediments, 7-Transitional-marine sediments, 8-Continental sediments, 9-Basement Complex (DU-Dumbulwa Member, DF-Deba Fulani Member, GU-Gulani Member).

\section{MATERIALS AND METHODS}

Topographic maps of Bima hill and environs that are located within the Gongola Sub-basin were employed in the fieldwork of this research to identify potential areas where the Bima Formation are well exposed. Along these well exposed outcrops identified, lithostratigraphic sections of this Formation outcropping around Bima hill were systematically logged to record data on lithologic variations, texture, bed geometry, paleocurrents, sedimentary structures and fossil content. Based on facies concept and application of Walters law in conjunction with facies relation provided by sedimentologic studies on ancient and modern environment, these data were utilized in 
designating lithofacies assemblages representing particular depositional environment. Paleocurrent measurements were also carried out on the abundant planar and trough crossbedded sandstones and the various orientations determined were used to evaluate provenance and hydrodynamic processes (e.g. Tucker, 2003). The dip and strike as well as the azimuth of the crossbeds were measured using compass clinometers in this analysis, and considering that the regional dips of the beds are generally greater than $10^{\circ}$, tilt correction was also carried out on the values using the procedure adopted by (Tucker, 2003).

\section{RESULT}

Facies St: trough crossbedded sandstone facies.

This lithofacies is generally composed of very coarse-grained sandstones that are dominantly poorly sorted with sub-angular to sub-rounded grains, and range in thickness from $1.5 \mathrm{~m}$ to $6 \mathrm{~m}$ (Fig. 4a). Basal boundaries are typically erosional and dominantly associated with mudclast and relatively few granules of quartz and feldspars. Cobbles and pebbles align these boundaries (Fig. 4f) and stacked successions units of up to $12 \mathrm{~m}$ thick are common. They are usually succeeded by rippled laminated sandstone (Sr) and mudstone (Fm) facies. This lithofacies was interpreted to have formed due to migrating sinuous 3-D dunes that stack up to generate bar forms in channel (Miall, 1978, 2010; Plint, 1983; Tucker, 2003).

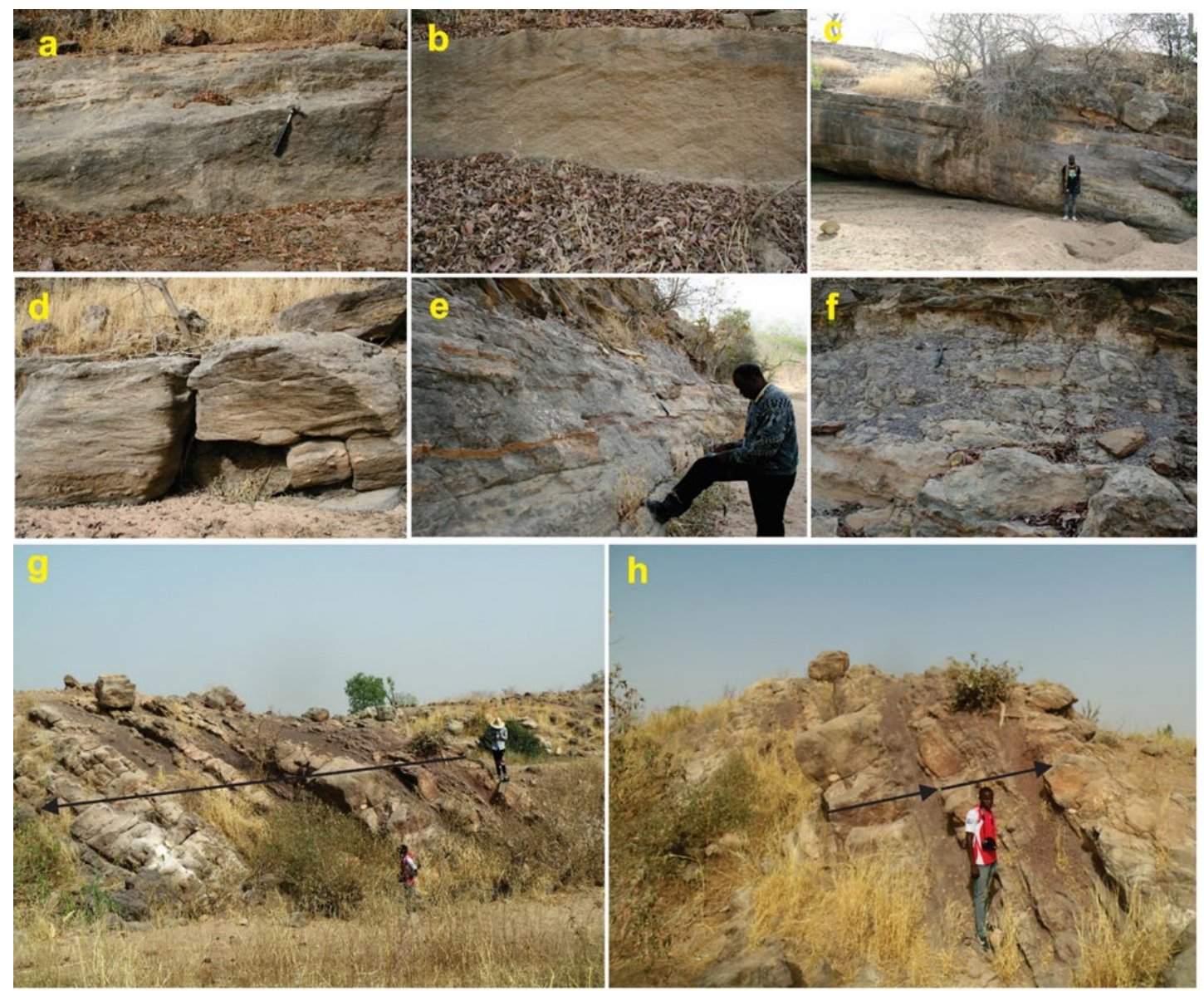

Fig.4a trough crossbedded sandstone, b) planar crossbedded sandstone, c) massive bedded sandstone , d) ripple laminated sandstone, e) parallel bedded sandstone, f) mudstone, g) coarsening upward cycle and h) fining upward cycle.

Facies Sp: tabular (planar) crossbedded sandstone facies.

This lithofacies is composed of poorly sorted medium-coarse grained sandstone with sub-angular grains, typically superposed trough crossbedded sandstone facies with thicknesses in the range of $50 \mathrm{~cm}-1 \mathrm{~m}$. Individual foresets occurring in mm scale (Fig. $4 \mathrm{~b}$ ). The units are commonly intercalated with trough crossbedded sandstone (St) and parallel bedded sandstone (Sl1). It This lithofacies was interpreted to have been produced from migration

International Journal of Research -GRANTHAALAYAH 
Syn-Rift Fluvio-Lacustrine Depositional System of The Cretaceous Bima Formation in The Gongola Sub - Basin, Northern Benue Trough, Ne, Nigeria

of 2-D dunes or sheet loading (Feary, 1984) while Miall $(1978,1996,2010)$ interpreted it as transverse bars formed under lower flow regime.

Facies Sm: massive sandstone facies.

This lithofacies is composed of poorly sorted medium- very coarse grained sandstone with sub-angular grains (Fig. 4c). It ranges in thickness between $50 \mathrm{~cm}$ and $2 \mathrm{~m}$, cobbles and pebbles and most commonly overlain by trough crossbedded sandstone facies (St) and ripple laminated sandstone facies (St). The facies was probably deposited on bars by stream floods or channelized flood flows around bars (Miall, 1978, 1996, 2010).

Facies Sr: ripple laminated sandstone facies.

This lithofacies is characterized by medium grained sandstone, but occasionally coarse grained demonstrating dominantly moderate sorting and sub-angular to sub-rounded grains (Fig. 4d). They are commonly overlain by mudstone facies (Fm) and where this facies is absent, parallel laminated sandstone facies (Sl) and massive bedded sandstones $(\mathrm{Sm})$ are found. Miall $(1978,1996)$ suggested it to have formed from migrating current ripples, under lower flow regime. Handford (1982) and Rust and Koster (1984) considered it as a product of waning flow sheet flood deposits.

Facies SII: parallel bedded sandstone facies.

This lithofacies consist of a poorly sorted medium- very coarse grained sandstone with sub-angular grains. Individual bed thickness ranges from $30 \mathrm{~cm}-1.2 \mathrm{~m}$, while laminations varied from 1 to $3 \mathrm{~cm}$ and are mostly underlain by trough crossbedded sandstone facies (St) (Fig. 4e). They are formed from either upper plane-bed phase lamination, or lower plane-bed phase lamination (e.g. Tucker, 2003). The bedded nature of the sandstone result from changing depositional conditions that causes variation either in grain size, content of clay and organic material, mineral composition or microfossil content of sediments. Miall $(1978,1996,2010)$, indicated that these facies were formed under plane bed flow (super-critical flow).

Facies Fm: mudstone facies.

This lithofacies is dark grey-black at the lower stratigraphic horizons of the Bima I Formation and light greypurple coloured at its uppermost limits with thicknesses ranging from $40 \mathrm{~cm}$ to $30 \mathrm{~m}$. They are generally devoid of bioturbations, but occasionally caliche nodules are locally present and are found commonly above trough crossbedded sandstone facies (St), planar crossbedded sandstone facies (Sp), and ripple laminated sandstone facies (Sr) (Fig.4f). It typically forms where water energy is sufficiently low to allow settling of suspended fine silt and clay (Miall, 1977; Rust, 1978; Tucker, 2003).

\section{SEDIMENTARY FACIES CHARACTERIZATION}

Temporal lithostratigraphic characterization of the facies of the syn-rift Bima I Formation at Bima hill outcrop of this formation indicated a dominance of coarsening upwards sequences. This progressively tapers to fining upward cycles towards the upper stratigraphic profile of Bima I Formation (Fig.4g and h). These coarsening upward cycles composes of thick black claystone/mudstone at base that gradually passing into succession of coarse grained and mudstones interbedded of mostly dark grey to black in the middle, and to thick light brown pebbly to very coarse-grained sandstone at top. The thick claystone /mudstone or shales usually occur in varying thickness (7$34 \mathrm{~m}$ ), which tends to reduce progressively in the uppermost cycles of the formation. The interbedded fine-grained sandstone and claystone occurring in the middle part of the cycle ranges in thickness from $3.2-21 \mathrm{~m}$. These units compose of ripple or parallel bedded sandstone that are locally host pebbles and cobbles, and are occasionally associated few units of massive beds. The thick light grey sandstone occurring in the topmost part of the coarsening upward cycle are $2.2 \mathrm{~m}-10 \mathrm{~m}$ thick, and are dominantly of trough crossbedded sandstone and massive sandstone. Locally, planar crossbedded sandstone and ripple laminated sandstone are also common. Above the coarsening upward cycles occurs the vertically stacked fining upward cycles with increasing propensity at the upper stratigraphic levels of this formation where they essentially define the architectural framework. The fining upward cycles of light grey very coarse-grained trough crossbedded sandstones (1.5 - 4m thick) with erosional contact associated with mudclasts at the base which temporally transit into grey claystones of about 40-60 cm thick. 


\section{LITHOFACIES ASSEMBLAGE}

The lithofacies in the Bima I Formation were grouped into two facies associations: Delta complex facies association (BAI) and Fluvial complex facies association (BAII)

Association BAI: Delta complex facies association

This facies association (Fig.5) is dominantly formed of coarsening upward cycle associated couplets of fining upward cycles demonstrating fluvio-lacustrine interactions. The coarsening upwards cycles is characterized by a procession of lacustrine mudstones at base that gradually interfingering with very coarse grained sandstones that often pebbly which are topped essentially by thick very coarse grained sandstones that forms the mouth bars in this delta complex. The interbedded sandstones are mostly massive bedded, whereas the mouth-bar units are generally trough crossbedded displaying abundant pebbles and cobble concentration and occasionally rock fragments are also present. The associated fining upwards cycles occurs above these units when present with a typical erosional contact showcasing assemblages of mudclasts and pebbles.

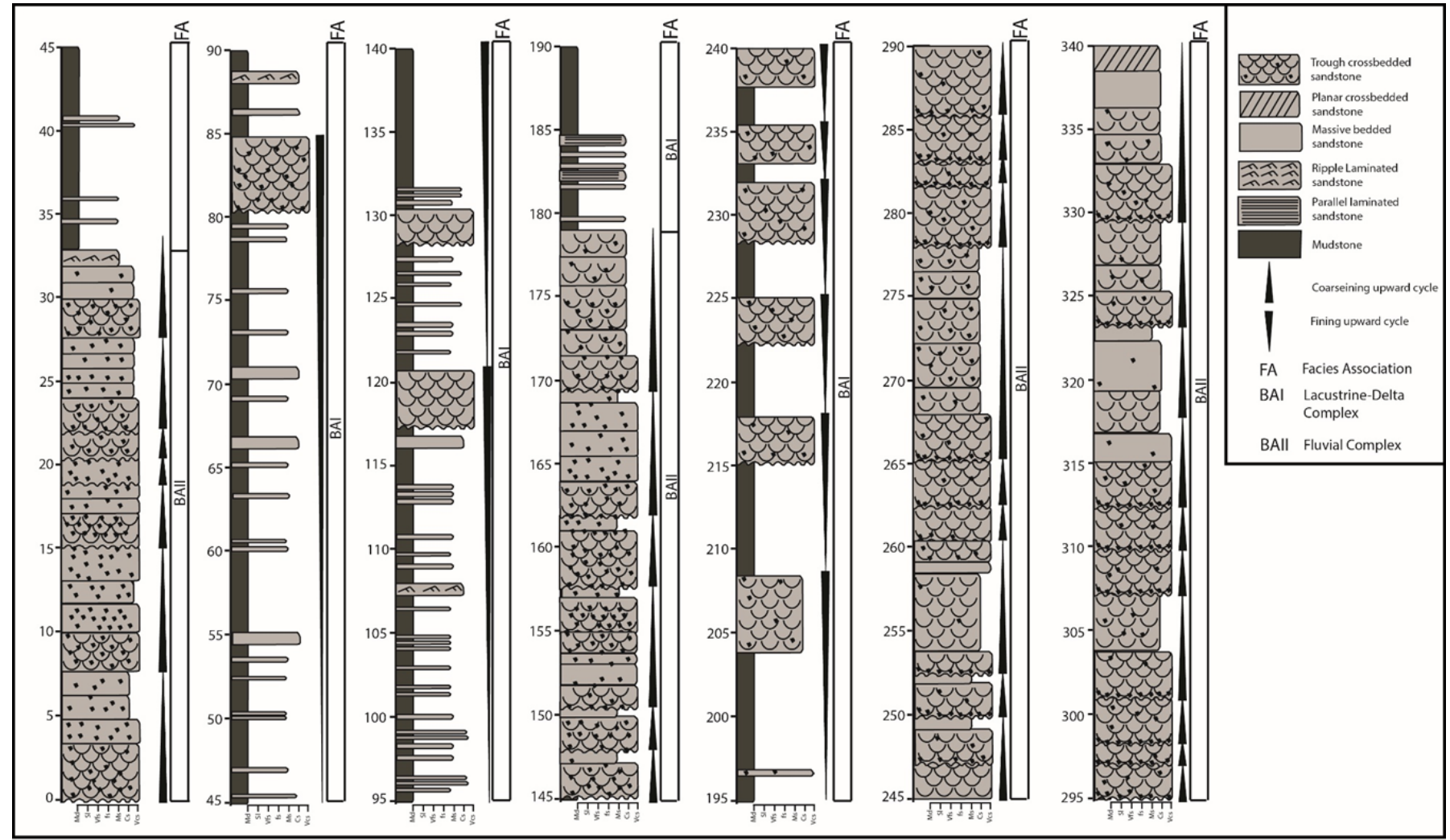

Fig.5 Lithologic Section of the Bima I Formation

\section{Association BAII: Fluvial complex facies Association}

This facies association consist of stacked amalgamated succession of fining upward cycles consisting of a very coarse grained, poorly sorted trough crossbedded sandstone facies (St) with erosional base having pebble lag deposits and mudclasts mostly capped by mudstone facies (Fm) and occasionally medium grained sandstones (Fig.5). Though that the facies association occur at the upper stratigraphic levels, at fringes its fringes, the sandstone of these fining upwards cycles transform to a dominantly fine-medium grained sandstones and the mudstones facies are mostly purple colored.

\section{DISCUSSION}

The structural configuration of the Gongola Sub-basin built of half graben system provided the template for the evolution of the facies assemblages in the syn-rift Bima I Formation which indicated the development of lacustrine, 
deltaic and fluvial depositional environment in the non-marine rift complex (Fig.6). Interfingering emplacement of these depositional styles are largely controlled by subsidence, tectonics and climate, powered by the balance between rate of creation of accommodation space and sediment supply (Gawthrope and Leader, 2002). Ideally, the dominant depositional setting in this syn-rift system are the fluvial environment which required relatively steep slope to develop and propagate axially and the lacustrine settings that are dependent on the basin outlet that perched above the depositional system whereas the development of the delta is a confluence product of the interaction between these two environment (Lambaise, 1990; Withjack et al., 2002). The overlapping interrelationship between the accommodation space sediment supply and water predetermines which out of depositional environment in a particular rift basin. The stratigraphic architecture of the syn-rift Bima I Formation indicated a clear reflection in temporal changes in these basin defining phenomenal attributes. The basal sequence of this formation is characterized by stacked succession of fluvial cycles accounts for a phase where the rate of sediment supply exceeds the incremental accommodation space, suggesting a concurrent low subsidence rate for the basin (e.g. Catuneanu, 2006). Improved subsidence initiated the generation of lacustrine system, because of the starved sediment supply, improved accommodation and likely favorable humid climatic conditions. The associated deltaic phase in these assemblage accounts for a period of high sediment impulse than normal most probably tectonically and climatically driven from a steep slope boundary normal fault system (e.g. Einsele, 2000: Catuneanu, 2006). Post-dating these lacustrine phases in the stratigraphic architecture of Bima I Formation are renewed overwhelming fluvial discharges accruing from accommodation creation, thus supporting the formation of the fluvial system that characterizes the upper stratigraphic horizon of the Bima I Formation.

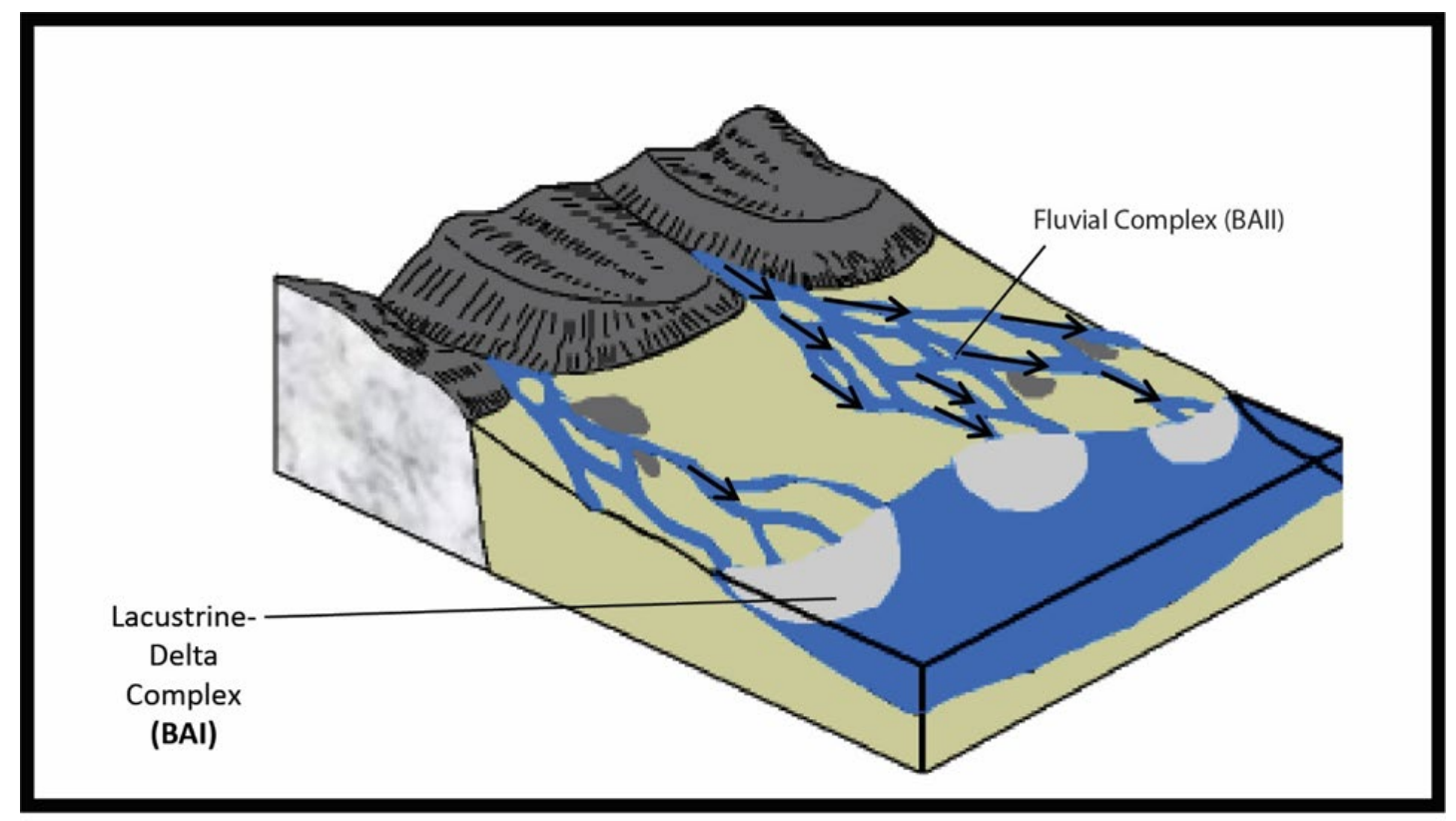

Fig.6 The geomorphic model for Syn-Rift Bima Formation

\section{CONCLUSION}

The syn-rift sequence of the Bima I Formation indicated the assemblages of trough crossbedded sandstones facies, planar crossbedded sandstone facies, massive bedded sandstone facies, ripple laminated sandstone facies, parallel bedded sandstone facies and mudstones facies. The association of these facies gave rise to fining and coarsening upward cycles that are reflective of fluvial complexes that are product of a scenario of greater sediment discharge than incremental accommodation space, and a lacustrine-delta complexes that reveals a phase of high rate of creation than sediment supply respectively. the lacustrine delta complexes are typically constricted to the lower stratigraphic zones of the Bima I Formation while the fluvial complexes predominating the upper stratigraphic levels of the formation 
Shettima Bukar, Mohammed Bukar, and Fatima Dupe Adams

\section{SOURCES OF FUNDING}

This research received no specific grant from any funding agency in the public, commercial, or not-for-profit sectors.

\section{CONFLICT OF INTEREST}

The author have declared that no competing interests exist.

\section{ACKNOWLEDGMENT}

None.

\section{REFERENCES}

[1] Abdulkarim H. A., Mamman Y.D, Abubakar, M.B., Babangida S.Y.D., John, S. J., and Shettima, B. (2017) Paleodepositional environment and age of Kanawa Member of Pindiga Formation, Gongola Sub-basin, Northern Benue Trough, NE Nigeria: Sedimentological and palynological approach. Journal of African Earth Sciences, 134, 345-351;

[2] Adegoke, O. S., Agumanu, A. E., Benkhelil, J. and Ajayi, P. O. (1978) New stratigraphic sedimentaologic and structural data on the Kerri-Kerri Formation, Bauchi and Borno States, Nigeria. Journal of African Earth Sciences, 5, 249 - 277.

[3] Avbovbo, A.A., Ayoola, E.O., Osahon, G.A., (1986). Depositional and structural styles in the Chad Basin of northeastern Nigeria. Bull. Am. Assoc. Pet. Geol. 70, 1787-1798.

[4] Benkhelil, J. (1989). The origin and evolution of the Cretaceous Benue Trough (Nigeria). Journal of African Earth Sciences, 8, 251 - 282.

[5] Catuneanu, O. (2006). Principles of Sequence Stratigraphy. Amsterdam, Elsevier, 234p.

[6] Dike, E. F. C. (1993) The Stratigraphy and structure of the Kerri-Kerri Basin Northeastern Nigeria. Journal of Mining and Geology, 29(2), 77 - 93.

[7] Dike, E. F. C. (2002). Sedimentation and tectonic evolution of the Upper Benue Trough and Bornu Basin, Northeastern Nigeria. Nig. Min. Geosci. Soc. 38th Annual and international confer., Port Harcourt, 45p.

[8] Dike, E. F. C. and Onumara, I. S. (1999) Facies and facies architecture, and depositional environments of the Gombe Sandstone, Gombe and Environs, NE Nigeria. Science Association of Nigeria Annual Conference, Bauchi, 67.

[9] Einsele, G., (2000). Sedimentary Basins, Evolution, Facies and Sediment Budget, second ed. Springer e Verlag, Berlin. 267p.

[10] Fairhead, J. D. and Binks, R. M. (1991). Differential opening of the Central and South Atlantic Oceans and the opening of the west African rift system. Tectonophysics, 187, 181 - 203.

[11] Fairhead, J.D., Green, C.M., Masterton, S.M. and Guiraud, R. (2013). The role that plate tectonics, inferred stress changes and stratigraphic unconformities have on the evolution of the West and Central African Rift System and the Atlantic continental margins. Tectonophysics, 594, 118-127.

[12] Feary, D.A., (1984). The Boambolo formation: a Silurian prograding fan delta sequence in Southeastern, New South Wales, Australia. Sediment. Geol. 39 (1e3), 169-195.

[13] Gawthorpe, R.L., Leeder, M.R., (2000). Tectono-sedimentary evolution of active extensional basins. Basin Res. $12,195-218$.

[14] Genik, G. J. (1992). Regional framework, structural and petroleum aspects of rift basin in Niger, Chad and Central African Republic (CAR). In: Geodynamics of rifting, Volume II, Case History Studies on Rift: North and South America and Africa (Eds P. A. Zeigler), Elsevier, 213, 169 - 185.

[15] Genik, G. J. (1993) Petroleum Geology of the Cretaceous - Tertiary Rift Basin in Niger, Chad and Central African Republic. American Association of Petroleum Geologists Bulletin, 77(8), 1405 - 1434.

[16] Guiraud. M. (1990). Tectono-sedimentary framework of the Early Cretaceous continental Bima Formation (Upper Benue Trough N.E. Nigeria). Journal of African Earth Sciences, 10, 341 - 353. 
Syn-Rift Fluvio-Lacustrine Depositional System of The Cretaceous Bima Formation in The Gongola Sub - Basin, Northern Benue Trough, Ne, Nigeria

[17] Handford, C.R., (1982). Sedimentology and evaporate genesis in a Holocene continental - Sabkha Playa basinBristol Dry Lake, Califonia. Sedimentology 29 (2), 239-253.

[18] Haq, B. U., Hardenbol, J. and Vail, P. R. (1987) Chronology of fluctuating sea levels since the Triassic (250 million years ago to present). Science, 235, 1156-1166.

[19] Lambiase, J.J., (1990). A model for tectonic control of lacustrine stratigraphic sequences in continental rift basins. In: Katz, B.J. (Ed.), Lacustrine Basin Explorationd Case Studies and Modern Analogs: American Association of Petroleum Geologists, vol. 50. Memoir, pp. 265-276.

[20] Miall, A.D., (1978). Lithofacies types and vertical profile models of braided river deposits, a summary. In: Miall, A.D. (Ed.), Fluvial Sedimentology, vol. 5. Canadian Society of Petroleum Geologists Memoir, pp. 597-604.

[21] Miall, A.D., (1996). The Geology of Fluvial Deposits. Springer-Verlag, Berlin, 582p

[22] Miall, A.D., (2010). Alluvial deposits. In: James, N.P., Dalrymple, R.W. (Eds.), Facies Models 4. Geological Association of Canada, St. John's, Newfoundland, pp. 105-137.

[23] Nwajide, C. S. (2013) Geology of Nigeria's sedimentary basins., CCS Bookshop Ltd, Lagos, 86pp.

[24] Plint, A.G., (1983). Facies, environment and sedimentary cycles in the middle Eocene, Bracklesham Formation of Hamshire Basin: evidence for sea-level change? Sedimentology 30, 625-653.

[25] Rust, B.R., (1978). A classification of alluvial channel systems. In: Maill, A.D. (Ed.), Fluvial Sedimentology, vol. 5. Canadian Society of Petroleum Geologists, Memoir, pp. 187-198.

[26] Rust, B.R., Koster, E.H., (1984). Coarse alluvial deposits. In: Walker, R.G. (Ed.), Facies Models, second ed., vol. 1. Geological Society of Canada, Reprint Series, pp. 53-69.

[27] Schlische, R.W., Olsen, P.E., (1990). Quantitative filling model for continental extensional basins with applications to early Mesozoic rifts of eastern North America. J. Geol. 98, 135-155.

[28] Shettima, B. (2016) Sedimentology, Stratigraphy and Reservoir Potentials of the Cretaceous Sequences of the Gongola Sub e Basin, Northern Benue Trough, NE Nigeria. Unpublished PhD Dissertation. Abubakar Tafawa Balewa University, Bauchi, 267pp.

[29] Shettima, B., Abubakar, M.B., Kuku, A. and Haruna, A.I. (2018) Facies Analysis, Depositional Environments and Paleoclimate of the Cretaceous Bima Formation in the Gongola Sub - Basin, Northern Benue Trough, NE Nigeria. Journal of African Earth Sciences, 137, 193-207.

[30] Shettima, B., Dike, E. F. C., Abubakar, M. B., Kyari, A. M. and Bukar, F. (2011) Facies and facies architecture and depositional environments of the Cretaceous Yolde Formation in the Gongola Basin of the Upper Benue Trough, northeastern Nigeria. Global Journal, 10(1), 67 - 75.

[31] Smoot, J.P., (1991). Sedimentary facies and depositional environments of early Mesozoic Newark Supergroup basins, eastern North America. Palaeogeogr Palaeoclimatol. Palaeoecol. 84, 369-423.

[32] Tucker, M. E. (2003). Sedimentary Rocks in the field. West Sussex, John Wiley \& Sons Ltd, 83 - 158p.

[33] Tukur, A., Samaila, N.K., Grimes, S.T., Kariya, I.I. and Chaanda, M.S. (2015). Two-member subdivision of the Bima Sandstone, Upper Benue Trough, Nigeria: based on sedimentological data. J. Afr. Earth Sci., 104, 140158.

[34] Withjack, M.O., Schlische, R.W., Olsen, P.E., (2002). Rift-Basin structure and its influence on sedimentary systems: sedimentation in continental rifts. Soc. Sediment. Geol. Special Publ. 73, 57-81

[35] Zaborski, P., Ugodulunwa, F., Idornigie, A., Nnabo, P. and Ibe, K. (1997) Stratigraphy, Structure of the Cretaceous Gongola Basin, Northeastern Nigeria. Bulletin Centre Researches Production Elf Aquitatine, 22, $153-185$. 